\title{
Penetrating keratoplasty: indications over a 10 year period
}

\section{N Al-Yousuf, I Mavrikakis, E Mavrikakis, S M Daya}

Br J Ophthalmol 2004;88:998-1001. doi: 10.1136/bjo.2003.031948

\begin{abstract}
Aims: To determine the indications for penetrating keratoplasty (PK) at the Corneoplastic Unit and Eye Bank, UK, a tertiary referral centre, over a 10 year period.

Methods: Records of all patients who underwent PK at our institution between 1990 and 1999 were reviewed retrospectively. Of the 1096 procedures performed in this period, 784 records were available for evaluation (72\%).

Results: Regrafting was the most common indication, accounting for $40.9 \%$ of all cases. Keratoconus was the second most common indication (15\%), followed by Fuchs' endothelial dystrophy (9.3\%), pseudophakic bullous keratopathy $(7.6 \%)$, and viral keratitis $(5.9 \%)$, which included both herpes simplex and herpes zoster and showed a statistically significant decreasing trend using regression analysis $(p<0.005)$. Among the regraft subgroup, viral keratitis accounted for $21.2 \%$ as the underlying primary diagnosis. The most common cause for graft failure in the regraft subgroup was endothelial failure (41.8\%).

Conclusion: Regrafting is the leading indication for PK; viral disease-although declining - is the leading primary diagnosis.
\end{abstract}

(fig 1). Regrafts were further analysed for the aetiology of failure of the previous graft and original diagnosis.

Statistical significance was determined using $\chi^{2}$ analysis. A combination of linear regression and $t$ test were used to establish linear trends and to determine the statistical significance of the trend.

\section{RESULTS}

Of the 784 cases performed, $714(91 \%)$ had the graft performed for visual reasons. Sixty five $(8.3 \%)$ were for therapeutic reasons such as unresponsive infection $(n=13$, $1.7 \%)$, threatened perforation $(\mathrm{n}=9,1.1 \%)$, and actual perforation $(n=43,5.5 \%)$. Only five cases $(0.6 \%)$ were performed for cosmetic reasons. Of 13 eyes which had a PK for infection, seven cases were bacterial, one Acanthamoeba, and in the five remaining cases the infectious agent was unknown.

The mean patient age was 54.21 years with a standard deviation (SD) of 21.46 and a median of 56.5 years. The mean ages for the main diagnoses were regrafts 54.4 (SD 19.66) years, keratoconus 32.5 (SD 11.70) years, herpes infection 55.5 (SD 20.87) years, Fuchs' endothelial dystrophy 70 (SD 10.37) years, and pseudophakic bullous keratopathy (PBK) 75 (SD 9.74) years.

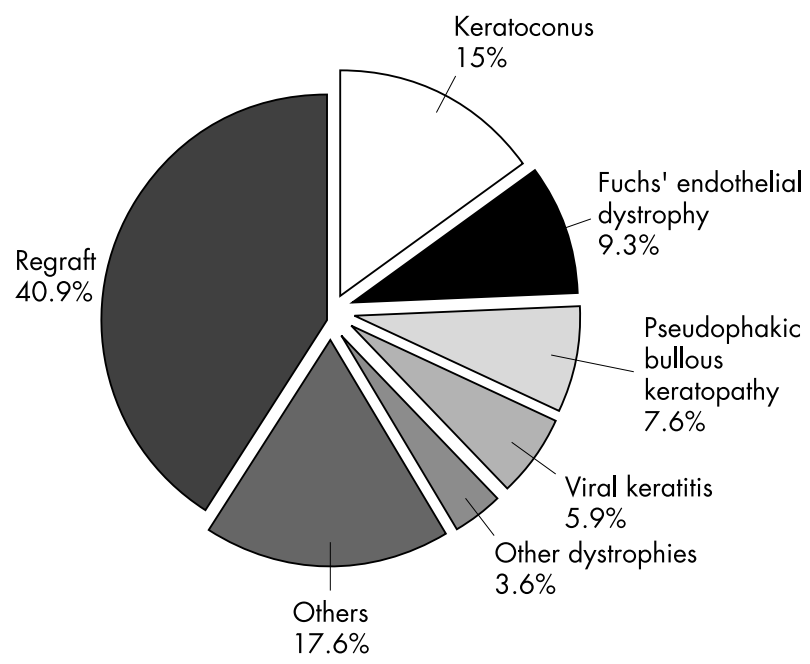

Figure 1 Indications for penetrating keratoplasty (PK), 1990-1999. Regraft $(n=321,40.9 \%)$ was the most common indication for PK. Keratoconus was the second most common diagnosis $(n=118,15 \%)$, followed by Fuchs' endothelial dystrophy $(n=73,9.3 \%)$, pseudophakic bullous keratopathy $(n=60,7.6 \%)$, viral keratitis $(n=46,5.9 \%)$, and other dystrophies $(n=28,3.6 \%)$. These six indications account for $82.3 \%$ of indications for PK. Aphakic bullous keratopathy, injuries, interstitial keratitis, and ulcerative keratitis accounted for most of the remaining cases $(n=138,17.6 \%)$.

could be retrieved from the booking register, we elected not to include these as there was little correlation between the data recorded in the operative note and the register. Information obtained was analysed with respect to age, sex, eye grafted, and preoperative clinical diagnosis. The indications for PK were divided into seven diagnostic categories
Abbreviations: HSV, herpes simplex virus; PBK, pseudophakic bullous keratopathy; PK, penetrating keratoplasty. 

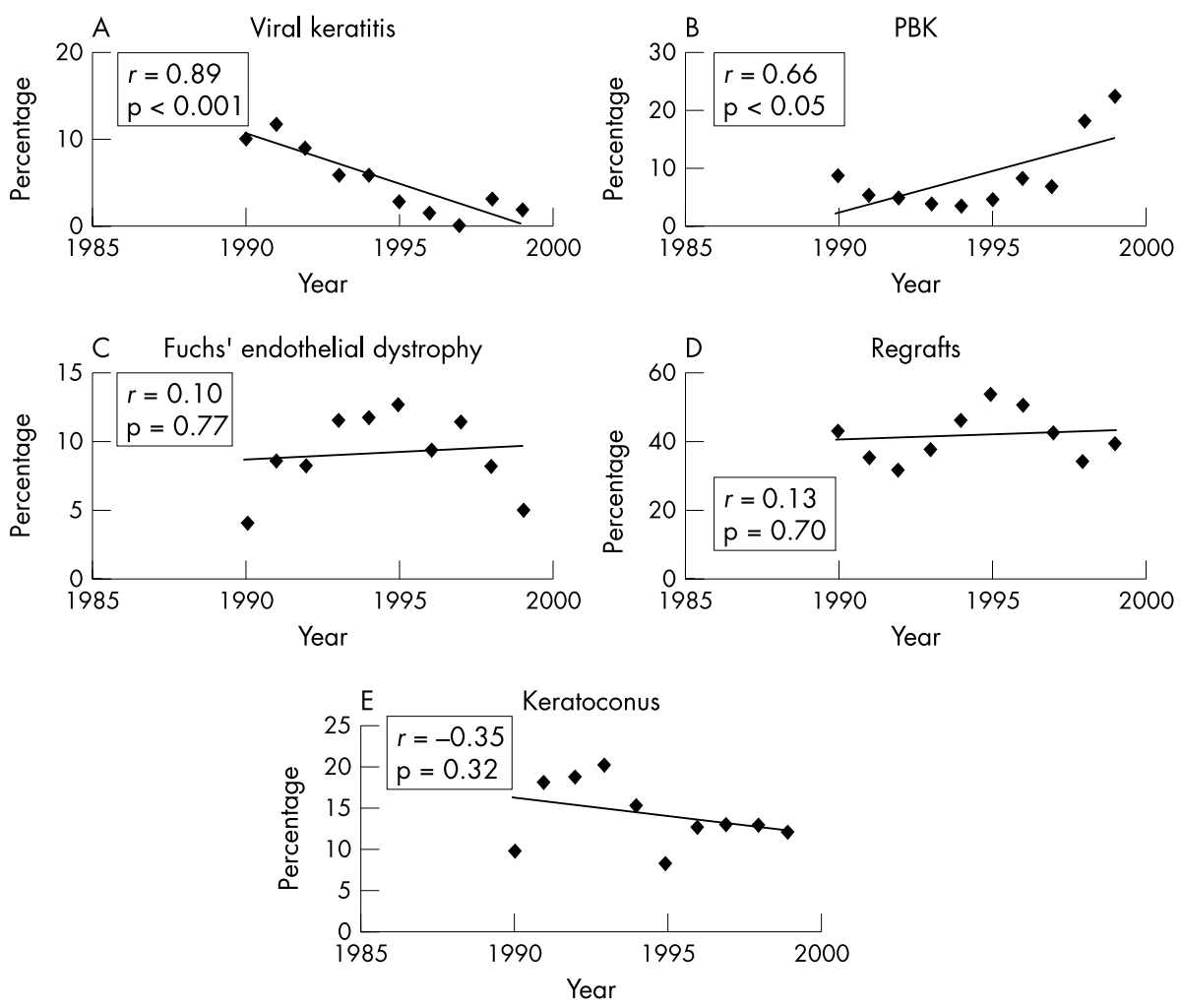

Overall, sex distribution showed slight male predominance with $54.7 \%$ males and $45.3 \%$ females. Using $\chi^{2}$ analysis for sex differences by diagnostic categories there was a statistically significant predominance among males with keratoconus (79 males, 39 females; $p<0.001$ ). No significant sex difference was found for the other diagnostic categories. The trends of the main indications for PK are illustrated in figure 2 .

The underlying primary diagnosis and the reason for graft failure in the regraft subgroup were evaluated (table 1). Surgical procedures associated with PK are illustrated in table 2 .

Figure 3 illustrates the comparison of the current indications for PK with those studied in the previous two decades. ${ }^{4}$

Table 1 Analysis of regrafts: original diagnosis and cause of failure

\begin{tabular}{|c|c|c|c|}
\hline \multicolumn{2}{|l|}{ Original diagnosis } & \multicolumn{2}{|l|}{ Causes of failure } \\
\hline $\begin{array}{l}\text { Viral keratitis } \\
\text { Dystrophies } \\
\text { Bullous keratopathy } \\
\text { Trauma } \\
\text { Keratoconus } \\
\text { Ulcerative keratitis } \\
\text { Corneal opacities } \\
\text { Others } \\
\text { Unknown }\end{array}$ & $\begin{array}{l}68(21.2 \%) \\
49(15.2 \%) \\
47(14.6 \%) \\
44(13.7 \%) \\
41(12.8 \%) \\
10(3.1 \%) \\
10(3.1 \%) \\
40(12.5 \%) \\
12(3.7 \%)\end{array}$ & $\begin{array}{l}\text { Endothelial failure } \\
\text { Endothelial rejectiont } \\
\text { Astigmatism } \\
\text { Recurrence of dystrophy } \\
\text { Perforation } \\
\text { Bacterial infection } \\
\text { Scarring } \\
\text { Primary donor failure } \\
\text { Recurrent HSV keratitis } \\
\text { Impending perforation } \\
\text { Bacterial infection with } \\
\text { perforation } \\
\text { Glaucoma } \\
\text { Trauma } \\
\text { Others } \\
\text { Unknown } \\
\text { Total }\end{array}$ & $\begin{array}{c}134(41.8 \%) \\
53(16.5 \%) \\
20(6.2 \%) \\
y 15(4.7 \%) \\
15(4.7 \%) \\
13(4 \%) \\
12(3.7 \%) \\
7(2.2 \%) \\
7(2.2 \%) \\
6(1.9 \%) \\
5(1.5 \%) \\
5(1.5 \%) \\
3(0.9 \%) \\
14(4.4 \%) \\
12(3.7 \%) \\
321(100 \%)\end{array}$ \\
\hline $\begin{array}{l}\text { *Endothelial failure } \\
\text { †Endothelial rejectio } \\
\text { HSV, herpes simplex }\end{array}$ & $\begin{array}{l}\text { unrelated to e } \\
\text { on leading to } \\
\text { x virus. }\end{array}$ & $\begin{array}{l}\text { ndothelial rejection. } \\
\text { endothelial failure. }\end{array}$ & \\
\hline
\end{tabular}

\section{DISCUSSION}

The Corneoplastic Unit and Eye Bank is a tertiary referral centre that deals primarily with corneal and anterior segment disorders. The indications for PK are not representative of those nationwide and clearly reflect the specialty nature of the institution (table 3). The category "other" in the table provided by UK Transplant accounted for $28 \%$ of indications. This is erroneous and reflects the operating surgeons' unwillingness to categorise indications according to the list provided in the Transplant Record Form.

Regrafting accounted for $40.9 \%$ of all PKs over 10 years, a figure that has essentially not changed from the last series spanning two decades $(40.8 \%))^{4}$ It was also one of the leading indications at a number of institutions in Europe and North America. $^{23}$ 5-8 2021 Regrafting can be expected to remain a leading indication for PK with the expanding pool of PK recipients and endothelial failure as a leading cause of graft failure. However with the growing interest in lamellar

Table 2 Surgical procedures associated with penetrating keratoplasty. All cases that had an anterior chamber lens implanted, underwent surgery from 199093

\begin{tabular}{|c|c|c|c|c|}
\hline & $\mathrm{PK}+\mathrm{ECCE}+\mathrm{IOL}$ & $\begin{array}{l}\text { Secondary } \\
\text { IOL } \\
\text { (aphakic) }\end{array}$ & $\begin{array}{l}\text { IOL exchange } \\
\text { primary } \\
\text { implant }\end{array}$ & $\begin{array}{l}\text { At } \\
\text { exchange }\end{array}$ \\
\hline $\mathrm{AClOL}$ & $5(3.4 \%)$ & $8(12 \%)$ & $35(67.3 \%)$ & $12(23 \%)$ \\
\hline $\mathrm{PClOL}$ & $140(94.6 \%)$ & $10(15 \%)$ & $2(3.8 \%)$ & $6(11.5 \%)$ \\
\hline $\begin{array}{l}\text { Transsclerally } \\
\text { sutured IOL }\end{array}$ & $3(2 \%)$ & $48(73 \%)$ & $1(1.9 \%)$ & $34(65.5 \%)$ \\
\hline $\begin{array}{l}\text { Iris fixated } \\
\mathrm{IOL}\end{array}$ & 0 & 0 & $8(15.4 \%)$ & 0 \\
\hline Unknown & 0 & 0 & $6(11.5 \%)$ & 0 \\
\hline Total & 148 & 66 & 52 & 52 \\
\hline
\end{tabular}

$\mathrm{PK}$, penetrating keratoplasty; ECCE, extracapsular cataract extraction; $\mathrm{IOL}$, intraocular lens implant; $\mathrm{ACIOL}$, anterior chamber $\mathrm{IOL}$; $\mathrm{PCIOL}$, posterior chamber $\mathrm{IOL}$. 


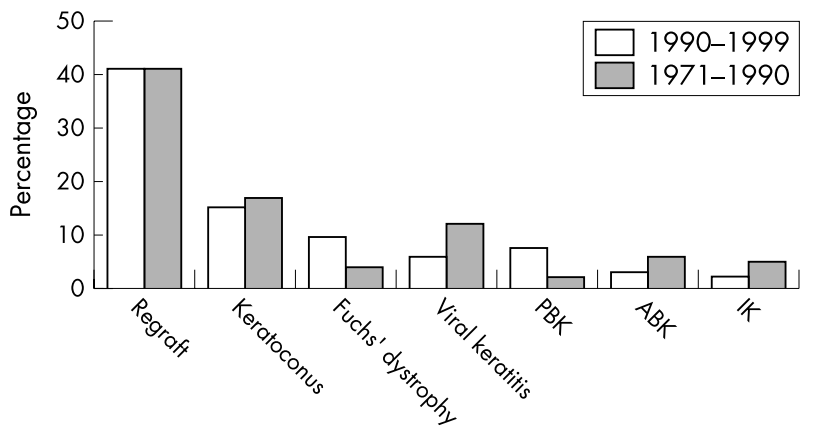

Figure 3 Comparison of distribution of indications for penetrating keratoplasty at the Corneoplastic Unit and Eye Bank between 1990-99 and 1971-90. Regrafting was the most common indication in both series (40.9\% and $40.8 \%$, respectively). Keratoconus was the second most common indication and similar in both series $115 \%$ and $16.8 \%$, respectively). Viral keratitis, which comprised $11.7 \%$ of the previous series, had a statistically significant decrease to $5.9 \%(p<0.005)$ in the present series. The frequency of both aphakic bullous keratopathy and interstitial keratitis were significantly higher in the previous series $(p<0.005)$. Both pseudophakic bullous keratopathy and Fuchs' endothelial dystrophy had a statistically significant increase in the present series $(p<0.005)$.

techniques, both deep and automated, the number of regrafts may in time decrease.

Viral keratitis comprising both herpes simplex and herpes zoster was the most common primary diagnosis in regrafts in our series, accounting for $21.2 \%$ of cases. The majority of these had a PK performed at another institution. Prophylactic antiviral treatment following PK has been used as standard practice at this institution since 1994. Acyclovir has been shown to significantly improve graft survival, and more common use of this modality may decrease the number of failed grafts from herpes simplex in the future. ${ }^{22-24}$ Viral keratitis was also the most common primary diagnosis in regrafts in previous reports from the UK, constituting $22-27 \% .{ }^{525}$ Additionally, this study shows a statistically significant decline in viral keratitis as an indication for primary PK. This is consistent with national UK data (table 3) and probably reflects better medical management of Herpetic keratitis through use of topical and systemic antivirals, increased appreciation of the higher risk of graft failure in this disease and a consequent reluctance to perform PK. Viral keratitis accounted only for $2.3 \%$ in the Doheny Eye Institute and also demonstrated a decreasing trend compared with earlier reports from the same institution. ${ }^{8}$ Brady et al also showed viral disease declining progressively. ${ }^{12}$ This decline, along with the use of systemic acyclovir, may in time reduce viral keratitis as a primary diagnosis for regrafts.

The most common cause for graft failure in regrafts was endothelial failure $(41.8 \%)$ followed by endothelial rejection (16.5\%). Primary failure accounted for $2.2 \%$ of regrafts. Sharif et $a l^{4}$ (1971-1990) reported a rate of $4.5 \%$ and Moorfields Eye Hospital (1985-1987) 5.8\%.5 This decrease in primary failure as a cause, reflects the improvement in eye banking over the last decade. Endothelial decompensation was also described at Moorfields Eye Hospital as the leading cause for graft failure. ${ }^{5}$ MacEwen et $a l,{ }^{25}$ in their study of regrafts, similarly demonstrated that allograft rejection and endothelial failure accounted for most graft failure causes.

Although keratoconus is the leading indication for PK nationally (23.5\%) (table 3 ), it was the second most common indication in this series (15\%) as it was previously between 1975 and 1990 (16.8\%). ${ }^{4}$ Keratoconus was more common in males in our series and similar preponderance has been reported previously, ${ }^{20}{ }^{26}$ although female predominance has also been described.$^{27-28}$ Keratoconus has and continues to be a leading indication for PK elsewhere 135921 29-30; however, with the resurgence of interest in lamellar techniques ${ }^{31-34}$ as well as the introduction of intracorneal rings, ${ }^{35}$ this may decrease in time.

Fuchs' endothelial dystrophy was the third most common indication at $9.3 \%$. The reported rates of Fuchs' endothelial dystrophy are highly variable ${ }^{810-1236-37}$ and probably due to different demographic pools and referral patterns. Although Fuchs' endothelial dystrophy is known to be more common

Table 3 Comparison of indications for penetrating keratoplasty nationally (yearly intervals)* and at the Corneoplastic Unit and Eye Bank (CUEB), 1990-99

\begin{tabular}{|c|c|c|c|c|c|c|c|c|c|c|c|c|c|}
\hline \multirow[b]{3}{*}{ Regraftt } & \multicolumn{11}{|c|}{ Primary disease nationally (\%) } & \multicolumn{2}{|c|}{$\begin{array}{l}\text { Primary disease at } \\
\text { CUEB, 1990-99 (\%) }\end{array}$} \\
\hline & \multicolumn{11}{|c|}{$\overline{1990199119921993199419951996199719981999 \text { Total }}$} & \multicolumn{2}{|l|}{ Total } \\
\hline & 0.1 & 0.1 & 0.1 & 0.2 & 0.1 & 0.4 & 0.4 & 0.6 & 0.8 & 0.8 & 0.36 & 640.9 & Regraftt \\
\hline Keratoconus & 19 & 20 & 20 & 23 & 26 & 24 & 27 & 26 & 25 & 25 & 23.5 & 15 & Keratoconus \\
\hline Fuchs' dystrophy & 8 & 8 & 10 & 11 & 10 & 11 & 11 & 13 & 13 & 13 & 10.8 & 9.3 & Fuchs' dystrophy \\
\hline $\begin{array}{l}\text { Endothelial failure: } \\
\text { pseudophakic } \\
\text { bullous keratopathy }\end{array}$ & 7 & 10 & 9 & 7 & 7 & 7 & 8 & 7 & 7 & - & 7.6 & 7.6 & $\begin{array}{l}\text { Pseudophakic } \\
\text { bullous } \\
\text { keratopathy }\end{array}$ \\
\hline $\begin{array}{l}\text { Endothelial failure: } \\
\text { aphakic bullous } \\
\text { keratopathy }\end{array}$ & 13 & 7 & 4 & 3 & 3 & 2 & 2 & 2 & 2 & - & 4.2 & & \\
\hline $\begin{array}{l}\text { Endothelial failure: } \\
\text { other }\end{array}$ & 6 & 4 & 2 & 2 & 2 & 1 & 2 & 2 & 2 & - & 2.5 & & \\
\hline $\begin{array}{l}\text { Chronic } \\
\text { inflammation: viral } \\
\text { keratitis }\end{array}$ & 6 & 5 & 3 & 4 & 3 & 3 & 3 & 3 & 2 & - & 3.5 & 5.9 & Viral keratitis \\
\hline $\begin{array}{l}\text { Chronic } \\
\text { inflammation: other }\end{array}$ & 6 & 5 & 4 & 3 & 3 & 3 & 3 & 2 & 1 & 3.2 & & & \\
\hline Aetiology uncertain & 3 & 4 & 6 & 5 & 5 & 4 & 3 & 3 & 3 & - & 4 & & \\
\hline Trauma: mechanical & 2 & 2 & 2 & 1 & 1 & 1 & 1 & 1 & 1 & - & 1.3 & & \\
\hline Other & 17 & 14 & 10 & 12 & 12 & 37 & 40 & 39 & 42 & 57 & 28 & 17.6 & Other \\
\hline \multirow[t]{2}{*}{$\begin{array}{l}\text { Ocular disease } \\
\text { unknown }\end{array}$} & 13 & 22 & 29 & 30 & 27 & 7 & 1 & 1 & 1 & 3 & 13.4 & & \\
\hline & & & & & & & & & & & & 3.6 & $\begin{array}{l}\text { Other } \\
\text { dystrophies }\end{array}$ \\
\hline
\end{tabular}


among females, ${ }^{203738}$ our study showed no statistically significant sex difference.

Although bullous keratopathy (aphakic and pseudophakic) has significantly declined nationally from $20 \%$ in 1990 to $9 \%$ in 1998 (table 3), this has not changed significantly as an indication for PK at our institution. However, as expected with increased use of intraocular lenses in cataract surgery in the mid 1980s, aphakic bullous keratopathy declined and PBK increased in our series (fig 3).

The incidence of PBK in the UK has been markedly lower than North America. Sharif et al ${ }^{4}$ reported 2\% between 1975 and 1990. Between 1990 and 1999, PBK accounted for 7.6\% in the UK (table 3 ) and the figure was identical in our series. In North America PBK became a leading indicator for PK in some series (Wills Eye Hospital 22.9\%, ${ }^{12}$ Doheny Eye Institute $24.8 \%^{8}$ ) and was a result of the initial enthusiasm for lens implantation in cataract surgery, particularly with anterior chamber closed loop implants and iris clip lenses. The UK, in its highly conservative approach and slower acceptance of intraocular lenses, avoided this epidemic. Interestingly, although the national rate of PBK remained the same over the 10 year period (table 3 ), at our institution the rate of PBK increased (fig 2B) - possibly reflecting an increase in referral of postcataract extraction complications requiring anterior segment reconstruction.

With changes in medical and surgical management, one expects a change in indications for corneal transplantation, and indeed this has been reflected nationally in the UK. However it is interesting to note that the overall indications for PK at a referral centre have not essentially changed over a period of 30 years. Regrafts have continued to be a leading indication at an identical rate in two series at the same institution with viral disease, which although declining, being the lead primary diagnosis. Through further improvements in medical management and the advent of better surgical techniques for lamellar grafting and newer techniques of posterior lamellar and endothelial transplantation, the indications for PK and the role of a referral corneal institution may well change over the next 30 years.

\section{ACKNOWLEDGEMENTS}

The authors gratefully acknowledge the assistance of Andrea Rowe, Eye Bank Coordinator, Dot Helme and Caroline Langridge, Department of Clinical Audit and Research, Queen Victoria Hospital, East Grinstead, and Phil Pocock, Senior Biostatistician, UK Transplant.

\section{Authors' affiliations}

N Al-Yousuf, I Mavrikakis, E Mavrikakis, S M Daya, Corneoplastic Unit and Eye Bank, Queen Victoria Hospital, East Grinstead, UK

Presented in part at "CORNEA 2002 - celebrating 50 years of Eye Banking", Gatwick, UK, 14 November 2002.

Correspondence to: Mr S M Daya, Director and Consultant Ophthalmic Surgeon, Corneoplastic Unit and Eye Bank, Queen Victoria Hospital, East Grinstead, West Sussex RH19 3DZ, UK; sdaya@compuserve.com

Accepted 5 January 2004

\section{REFERENCES}

1 Smith RE, McDonald HR, Nesburn AB, et al. Penetrating keratoplasty, Changing indications, 1947 to 1978. Arch Ophthalmol 1980;98:1226-9.
2 Lemp MA. Indications for penetrating keratoplasty. Med Ann DC 1972:41:346-50.

3 Arentsen JJ, Morgan B, Green WR. Changing indications for keratoplasty. Am J Ophthalmol 1976;81:313-18.

4 Sharif KW, Casey TA. Changing indications for penetrating keratoplasty, 1971-1990. Eye 1993;7:485-8.

5 Morris RJ, Bates AK. Changing indications for keratoplasty. Eye 1989;3:455-9.

6 Robin JB, Gindi JJ, Koh K, et al. An update of the indications for penetrating keratoplasty, 1979 through 1983. Arch Ophthalmol 1986;104:87-9.

7 Mohamadi P, McDonnell JM, Irvine JA, et al. Changing indications for penetrating keratoplasty, 1984-1988. Am J Ophthalmol 1989;107:550-2.

8 Flowers CW, Chang KY, McLeod SD, et al. Changing indications for penetrating keratoplasty, 1989-1993. Cornea 1995;14:583-8.

9 Damii KF, Rootman J, White VA, et al. Changing indications for penetrating keratoplasty in Vancouver, 1978-1987. Can J Ophthalmol 1990;25:243-8.

10 Lindquist TD, McGlothan JS, Rotkis WM, et al. Indications for penetrating keratoplasty: 1980-1988. Cornea 1991;10:210-16.

11 Hyman L, Wittpenn J, Yang C. Indications and techniques of penetrating keratoplasties, 1985-1988. Cornea 1992;11:573-6.

12 Brady SE, Rapuano CJ, Arentsen JJ, et al. Clinical indications for and procedures associated with penetrating keratoplasty, 1983-1988. Am J Ophthalmology 1989;108:118-22.

13 Chandler JW. Indications for penetrating keratoplasty and management of cases. Trans Pacific Coast Oto-ophthalmol Soc 1976;57:97-104.

14 Robinson $\mathrm{CH}$. Indications, complications and prognosis for repeat penetrating keratoplasty. Ophthalmic Surg 1979;10:27-34.

15 Ramsay AS, Lee WR, Mohammed A. Changing indications for penetrating keratoplasty in the West of Scotland from 1970 to 1995. Eye 1997; 11:357-60.

16 Haamann $\mathbf{P}$, Jensen $O M$, Schmidt $P$. Changing indications for penetrating keratoplasty. Acta Ophthalmol 1994;72:443-6.

17 Rapuano CJ, Cohen EJ, Brady SE, et al. Indications for and outcomes of repeat penetrating keratoplasty. Am J Ophthalmol 1990;109:689-95.

18 Brooks AMV, Weiner JM. Indications for penetrating keratoplasty: A clinicopathological review of 511 corneal specimens. Aust N Z J Ophthalmol 1987; 15:277-81

19 Kervick GN, Shepherd WFI. Changing indications for penetrating keratoplasty. Ophthalmic Surg 1990;21:227.

20 Maeno A, Naor J, Lee HM, et al. Three decades of corneal transplantation: indications and patient characteristics. Cornea 2000;19:7-11.

21 Cursiefen C, Kuchle M, Naumann GOH. Changing indications for penetrating keratoplasty: Histopathology of 1,250 corneal buttons. Cornea 1998; 17:468-70

22 Cobo LM, Coster DJ, Rice NSC, et al. Diagnosis and management of corneal transplantation for herpetic keratitis. Arch Ophthalmol 1980;98:1755-9.

23 Barney NP, Foster CS. A prospective randomised trial of oral acyclovir after penetrating keratoplasty for herpes simplex viral keratitis. Cornea 1994;13:232-6.

24 Tambasco FP, Cohen EJ, Nguyen $\mathrm{LH}$, et al. Oral acyclovir after penetrating keratoplasty for herpes simplex keratitis. Arch Ophthalmol 1999;1 17:445-9.

25 MacEwen CJ, Khan ZUH, Anderson E, et al. Corneal re-graft: indications and outcome. Ophthalmic Surgery 1988;19:706-12.

26 Liu E, Slomovic AR. Indications for penetrating keratoplasty in Canada, 19861995. Cornea 1997;16:414-19.

27 Pouliquen Y. Doyne lecture keratoconus. Eye 1987;1:1-14.

28 Kaufman H, Barron B, McDonald M. The cornea, 2nd ed. ButterworthHeinemann, 1998:369.

29 Mamalis N, Anderson CW, Kreisler KR, et al. Changing trends in the indications for penetrating keratoplasty. Arch Ophthalmol 1992:110:1409-11.

30 The Australian Corneal Graft registry, 1990-1992 report. Aust N Z J Ophthalmol 1993;21(suppl 2):1-48.

31 Anwar M, Teichman KD. Big-bubble technique to bare Descemet's membrane in anterior lamellar keratoplasty. J Cataract Refract Surg 2002;28:398-403.

32 Coombes AG, Kirwan JF, Rostron CK. Deep lamellar keratoplasty with lyophilised tissue in the management of keratoconus. $\mathrm{Br} J$ Ophthalmol 2001;85:788-91

33 Melles GR, Remeijer L, Geerards AJ. A quick surgical technique for deep, anterior lamellar keratoplasty using visco-dissection. Cornea 2000;19:427-32.

34 Balestrazzi E, Balestrazzi A, Mosca L, et al. Deep lamellar keratoplasty with trypan blue intrastromal staining. J Cataract Refract Surg 2002;28:929-31.

35 Colin J, Cochener B, Savary G, et al. Correcting keratoconus with intracorneal rings. J Cataract Refract Surg 2000;26:1117-22.

36 Legeais J, Parc C, D'Hermies F. Nineteen years of penetrating keratoplasty in the Hotel-Dieu Hospital in Paris. Cornea 2001;20:603-6.

37 Dobbins KRB, Price FW, Whitson WE. Trends in the indications for penetrating keratoplasty in the Midwestern United States. Cornea 2000;19:813-16.

38 Krachmer JH, Palay DA. Cornea. St Louis, USA: Mosby, 1995. 